\title{
Enhancing Germination Capacity of Chloris barbata under in-vitro Conditions
}

\author{
R. Narmadha, T. Selvakumar*, S. Srinivasan and C. R. Chinnamuthu \\ Department of Agronomy, TNAU, Coimbatore, Tamil Nadu, India \\ *Corresponding author
}

\section{Keywords}

Chloris barbata,

Water soaking,

$\mathrm{KNO}_{3}$,

Germination,

seed banks

\section{Article Info}

Accepted:

20 October 2020

Available Online:

10 November 2020

\section{A B S T R A C T}

Investigation was conducted at the laboratory at Tamil Nadu Agricultural University (TNAU), Coimbatore to enhance the germination capacity of Chloris barbata under invitro conditions with water and Potassium nitrate $\left(\mathrm{KNO}_{3}\right)$. The species performed poor for germination rate when placed in the petri plate at room temperature. To attain the germination rate and the uniformity of the germination an experiment was performed with six treatments viz. $\mathrm{T}_{1}$ - Control (without $\mathrm{KNO}_{3}$ treatment and soaking), $\mathrm{T}_{2}$ - Soaking of seeds in water for $6 \mathrm{hrs}, \mathrm{T}_{3}$ - Soaking of seeds in water for $12 \mathrm{hrs}, \mathrm{T}_{4}$ - Seed treatment in $2 \% \mathrm{KNO}_{3}$ solution, $\mathrm{T}_{5}$ - Seed treatment in $2 \% \mathrm{KNO}_{3}$ solution with 6 hrs soaking and $\mathrm{T}_{6}$ Seed treatment in $2 \% \mathrm{KNO}_{3}$ solution with $12 \mathrm{hrs}$ soaking, all replicated four times. Germination behaviours of weed seeds were observed in all the treatments. The results showed that the germination percentage was significantly influenced by the seed treatment with $\mathrm{KNO}_{3}$ and seed soaking. Seeds treated with $2 \% \mathrm{KNO}_{3}$ solution with $12 \mathrm{hrs}$ soaking $\left(\mathrm{T}_{6}\right)$ recorded significantly higher seed germination $(63 \%)$ compared to other treatments. Mean germination time of $C$. barbata reduced significantly when it was treated with $2 \%$ $\mathrm{KNO}_{3}$ solution with soaking ( $6 \& 12 \mathrm{hrs} ; \mathrm{T}_{5} \& \mathrm{~T}_{6}$, respectively). The maximum speed of germination, coefficient of velocity of germination, mean daily germination, peak value and germination value was recorded when the $C$. barbata seeds were treated in $2 \% \mathrm{KNO}_{3}$ solution with $12 \mathrm{hrs}$ soaking.

\section{Introduction}

The soil is a resting place for weed seeds, and they are the main source of weed population, which reproduces sexually, by seeds. Due to presence of the weed seed dormancy it's very difficult to know the quantity of weed seeds in soil bank and this dormancy helps the seeds to thrive in soil over a period of time and cause threat to the crop production. To overcome these problems, the germination rate and uniformity of the weed seed germination has to be increased to attain reliable data from weed seed bank studies.

Chloris barbata, one of the annual or shortlived perennial species propagated through seeds, is an important weed in many tropical and subtropical regions. Under laboratory conditions C.barbata seeds were tested for germination and its response was very poor $(<$ $10 \%$ ). Suhas and Joshi (2013) reported that 
seeds of $C$. barbata showed little dormancy when germinated under non-saline conditions. Normally, to improve the seed germination it can be treated with water or any chemical to initiate the early germination process. Seed hydration with water encourages the germination by activating the enzymes and accelerates the starch and protein metabolism (Kikiuchi et al., 2006). Sometimes, the presence of seed coat delays the speed of germination. Under such conditions, Potassium nitrate $\left(\mathrm{KNO}_{3}\right)$ stimulates the partial germination of seeds (Silva et al., 2009).Despite some findings proved that the $\mathrm{KNO}_{3}$ accelerates the seed germination in tomato (Lara et al., 2014), Calotropispersica (Farajollahi et al., 2014), Perennial ryegrass (Danneberger et al., 1992). Shim et al., (2008) reported that $\mathrm{KNO}_{3}$ were used for breaking seed dormancy and promoting seed germination.

However, the duration of soaking also plays a major role in the germination behavior, which reduces the seeds natural defense against the germination and speeds up the process to initiate the germination. The study was conducted to find out the possible way to increase the germination percentage in Petridish to undertake the weed seed bank studies at normal conditions.

\section{Materials and Methods}

The present investigation was conducted at the laboratory in the Department of Agronomy, Agricultural College and Research Institute, Tamil Nadu Agricultural University (TNAU), Coimbatore, India, during 2019to study the effect of water soaking and Potassium nitrate $\left(\mathrm{KNO}_{3}\right)$ on the germination of C.barbata. Seeds of C.barbata were collected from the mature plants of weeds in the field and the seeds were sun dried for three days and the seeds were kept in glass bottles at room temperature for the experiment. Twenty-five healthy seeds of C.barbata with uniform size were selected for all the treatments. Seeds were kept in Petri dish over filter paper (Whatman No. 1) and allowed to germinate by providing optimum moisture. After confirmation of poor germination, the seed lot was used for further studies. The experiment consists of six treatments with four replications viz. $\mathrm{T}_{1}$ Control (Without $\mathrm{KNO}_{3}$ treatment and soaking), $\mathrm{T}_{2}$ - Soaking of seeds in water for 6 $\mathrm{hrs}, \mathrm{T}_{3}$ - Soaking of seeds in water for $12 \mathrm{hrs}$, $\mathrm{T}_{4}$ - Seeds treatment in $2 \% \mathrm{KNO}_{3}$ solution, $\mathrm{T}_{5}$ - Seeds treatment in $2 \% \mathrm{KNO}_{3}$ solution with 6 hrs soaking and $\mathrm{T}_{6}$ - Seeds treatment in $2 \%$ $\mathrm{KNO}_{3}$ solution with 12 hrs soaking. Germination behaviours of weed seeds were observed in all the treatments. Germinated seeds number was counted (seed radical emergence which attained $2 \mathrm{~mm}$ were considered as the germinated seeds) on daily basis and observed up to 10 days after sowing, after that seedling root and shoot length were also observed. At the end following observations were recorded.

Final germination percentage (FGP)(Orchard, 1977)

FGP $=\frac{\text { Number of seeds germinated }}{\text { Total numberof seeds }} \times 100$

Speed of germination (Maguire, 1962)

Speed of Germination $=\frac{\text { No. of seeds geminated }}{\text { Day of first count }}+\ldots . . .+\frac{\text { Number of seeds germinated }}{\text { Day of final count }}$

Mean daily germination (MDG) (Roberts, 1981)

$\mathrm{MDG}=\frac{\text { Final germination percentage }}{\text { Total number of days }}$

Mean Germination Time (MGT) (Orchard, 1977)

$\mathrm{MGT}=\frac{\sum(\mathrm{nd})}{\sum \mathrm{n}}$ 
Where, n- Number of seeds germinated; dNumber of days; $\sum \mathrm{n}$ - Total number of seeds germinated

Daily germination speed (DGS) Reshma and Basavaraj (2019)

$\mathrm{DGS}=\frac{1}{\mathrm{MDG}}$

Coefficient of velocity of germination (CVG) (Jones and Sanders 1987)

$\mathrm{CVG}=\frac{\mathrm{N} 1+\mathrm{N} 2+\ldots . \mathrm{Ni}}{100 \mathrm{~N} 1 \mathrm{~N} 1+\mathrm{N} 2 \mathrm{~T} 2+\ldots \mathrm{NiT} i}$

Where, $\mathrm{Ni}$ is the number of seeds germinated each day; $\mathrm{Ti}$ is the number of days from sowing corresponding to $\mathrm{N}$

Peak value (Cazabator, 1962)

Peak value $=\frac{\text { Highest seed germinated }}{\text { Number of days }}$

Germination value (Cazabator, 1962)

\section{GV $=$ PV X MDG}

Time to 50 percent germination (Farooq et al., 2005)

$T_{50}=T i+\frac{\left(\frac{N}{2}-N i\right)\left(T_{j}-T_{i}\right)}{N j-N i} \times 100$

Where, $\mathrm{t}_{50}$ is the median germination time, $\mathrm{N}$ is the final number of seed germinated and $\mathrm{Ni}$ and $\mathrm{Nj}$ are the total number of seeds germinated in the adjacent counts at time $\mathrm{Ti}$ and $\mathrm{Tj}$ respectively, when $\mathrm{Ni}<\mathrm{N} / 2<\mathrm{Nj}$.

\section{Results and Discussion}

\section{Germination percentage}

The germination percentage was significantly influenced by the seeds treatment with $\mathrm{KNO}_{3}$ and seed soaking. Non treated seeds $\left(\mathrm{T}_{1}\right)$ recorded poor germination $(<10 \%)$ and it was on par with the water soaking for $6 \mathrm{hrs}$. When soaking time was increased to $12 \mathrm{hrs}\left(\mathrm{T}_{3}\right)$ it recorded significantly higher germination percentage $(25 \%)\left(\mathrm{T}_{3}\right)$. Seeds treated with 2 per cent $\mathrm{KNO}_{3}$ solution had significantly positive effect on germination of $C$. barbata and also the germination percentage increases with increased time of soaking. Seeds treated with 2 per cent $\mathrm{KNO}_{3}$ solution with $12 \mathrm{hrs}$ $\left(\mathrm{T}_{6}\right)$ soaking recorded significantly higher seed germination $(63 \%)$ compared to other treatments and it was followed by the treatment in which seeds treated with 2 per cent $\mathrm{KNO}_{3}$ solution with $6 \mathrm{hrs}\left(\mathrm{T}_{5}\right)$ soaking (51 \%). The $\mathrm{KNO}_{3}$ treated seeds showed higher percentage of germination and it is in accordance with the results of Zavariyan et al., (2015). It may be due to the presence of nitrate $\left(\mathrm{NO}_{3}-\right)$ in $\mathrm{KNO}_{3}$ provided exogenously which acts as a signal molecule that favours the germination of C.barbata by involving in the gibberellins pathway (Alboresi et al., 2005) (Fig.1a-1b and Table 1).

\section{Mean germination time}

C. barbata shows significant response to the seeds treatment with respect to mean germination time. Mean germination time of C. barbata reduced significantly when it treated in $2 \% \mathrm{KNO}_{3}$ solution with soaking (6 $\& 12 \mathrm{hrs})\left(\mathrm{T}_{5} \& \mathrm{~T}_{6}\right)$. The treatment $\mathrm{T}_{4}$ recorded higher mean germination and it may be due to the lesser time for the imbibition of $\mathrm{KNO}_{3}$ solution, since the MGT depends on the imbibition process in which priming activates the internal metabolic activities required for further germination process (Basra et al., 2005).

Soaking of seeds in water for $12 \mathrm{hrs}\left(\mathrm{T}_{3}\right)$ recorded higher mean germination time when compared to seeds soaked in water for 6hrs $\left(\mathrm{T}_{2}\right)$, it may be due to increase in germination percentage at lower rate of germination. 


\section{Speed of germination}

The maximum speed of germination was recorded when the $C$. barbata seeds treated in $2 \% \mathrm{KNO}_{3}$ solution with 12 hrs soaking (3.40) and as soaking time decreases the germination speed also get decreased significantly. Seed of C. barbata without treatment of $2 \% \mathrm{KNO}_{3}$ solution recorded significantly lower speed of germination compared to the seeds treated with the $2 \% \mathrm{KNO}_{3}$ solution. Farooq et al., 2006 recorded that the $\mathrm{K}^{+}$improves the cell water status and also act as the cofactor in activities of various enzymes most of which are active when reserve mobilization and radical protrusion are in progress. Time of soaking which plays a role in the ease of imbibition process leads to readily available food during germination thus complete the process of germination in the shorter time (Kant et al., (2006); Kaur et al., (2005) and it is accordance with the present study (Table 2).

Table.1 Effect of seeds treatment on the germination indices of Chloris barbata

\begin{tabular}{|c|c|c|c|}
\hline Treatments & $\begin{array}{l}\text { Mean germination } \\
\text { time }\end{array}$ & $\begin{array}{c}\text { Speed of } \\
\text { germination }\end{array}$ & $\begin{array}{l}\text { Mean daily } \\
\text { germination }\end{array}$ \\
\hline $\begin{array}{l}\mathrm{T}_{1} \text { - Control (Without } \mathrm{KNO}_{3} \text { treatment } \\
\text { and soaking) }\end{array}$ & 5.13 & 0.36 & 0.29 \\
\hline$T_{2}$ - Soaking of seeds in water for $6 \mathrm{hrs}$ & 5.15 & 0.55 & 0.46 \\
\hline $\mathrm{T}_{3}$ - Soaking of seeds in water for $12 \mathrm{hrs}$ & 5.53 & 1.18 & 0.92 \\
\hline $\mathrm{T}_{4} \begin{array}{c}- \text { Seeds } \\
\text { solution }\end{array}$ & 5.98 & 1.86 & 1.54 \\
\hline $\begin{array}{c}\mathrm{T}_{5} \text { - Seeds treatment in } 2 \% \mathrm{KNO}_{3} \\
\text { solution with } 6 \text { hrs soaking }\end{array}$ & 4.75 & 2.76 & 1.90 \\
\hline $\begin{array}{c}\mathrm{T}_{6} \text { - Seeds treatment in } 2 \% \mathrm{KNO}_{3} \\
\text { solution with } 12 \mathrm{hrs} \text { soaking }\end{array}$ & 4.76 & 3.40 & 2.25 \\
\hline S.Ed & 0.28 & 0.13 & 0.12 \\
\hline C.D. $(p=0.05)$ & 0.59 & 0.28 & 0.26 \\
\hline
\end{tabular}

Table.2 Effect of seeds treatment on the Time to $50 \%$ germination, Peak value and Germination value

\begin{tabular}{|l|c|c|c|}
\hline \multicolumn{1}{|c|}{ Treatments } & $\begin{array}{c}\text { Time to 50 \% } \\
\text { germination }\end{array}$ & Peak value & $\begin{array}{c}\text { Germination } \\
\text { value }\end{array}$ \\
\hline $\begin{array}{l}\mathbf{T}_{\mathbf{1}} \text { - Control (Without } \mathbf{K N O}_{\mathbf{3}} \text { treatment and } \\
\text { soaking) }\end{array}$ & 4.38 & 0.23 & 0.07 \\
\hline $\mathbf{T}_{\mathbf{2}}$ - Soaking of seeds in water for 6 hrs & 4.38 & 0.32 & 0.15 \\
\hline $\mathbf{T}_{\mathbf{3}}$ - Soaking of seeds in water for 12 hrs & 5.13 & 0.54 & 0.50 \\
\hline $\mathbf{T}_{\mathbf{4}}$ - Seeds treatment in 2\% $\mathbf{K N O}_{\mathbf{3}}$ solution & 5.54 & 0.74 & 1.14 \\
\hline $\begin{array}{c}\mathbf{T}_{\mathbf{5}}-\mathbf{S e e d s} \text { treatment in 2\% } \mathbf{K N O}_{\mathbf{3}} \text { solution } \\
\text { with } \mathbf{6} \text { hrs soaking }\end{array}$ & 4.32 & 1.44 & 2.76 \\
\hline $\begin{array}{c}\mathbf{T}_{\mathbf{6}}-\text { Seeds treatment in 2\% } \mathbf{K N O}_{\mathbf{3}} \text { solution } \\
\text { with 12 hrs soaking }\end{array}$ & 4.26 & 1.75 & 3.96 \\
\hline $\begin{array}{c}\mathbf{S . E d} \\
\text { C.D.(p=0.05) }\end{array}$ & 0.44 & 0.08 & 0.27 \\
\hline
\end{tabular}


Fig.1a Effect of seeds treatment on the daily germination percentage of Chloris barbata

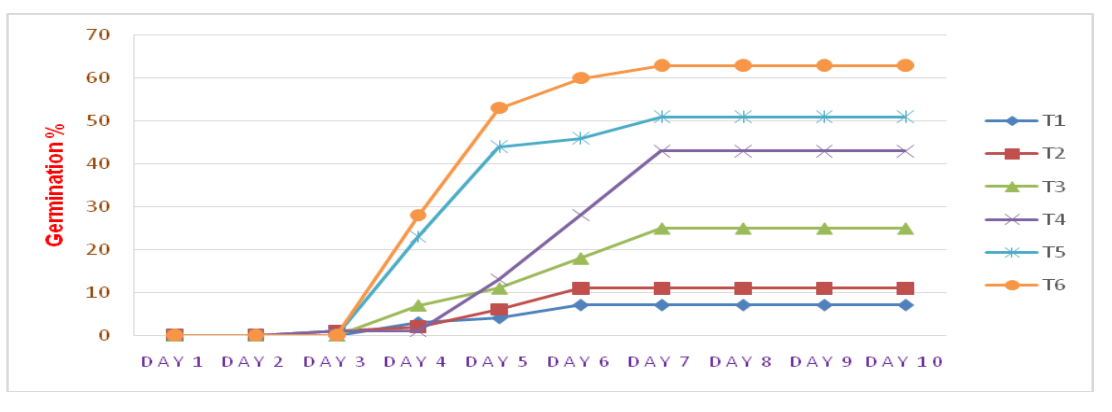

Fig.1b Effect of seeds treatment on the germination percentage of Chloris barbata

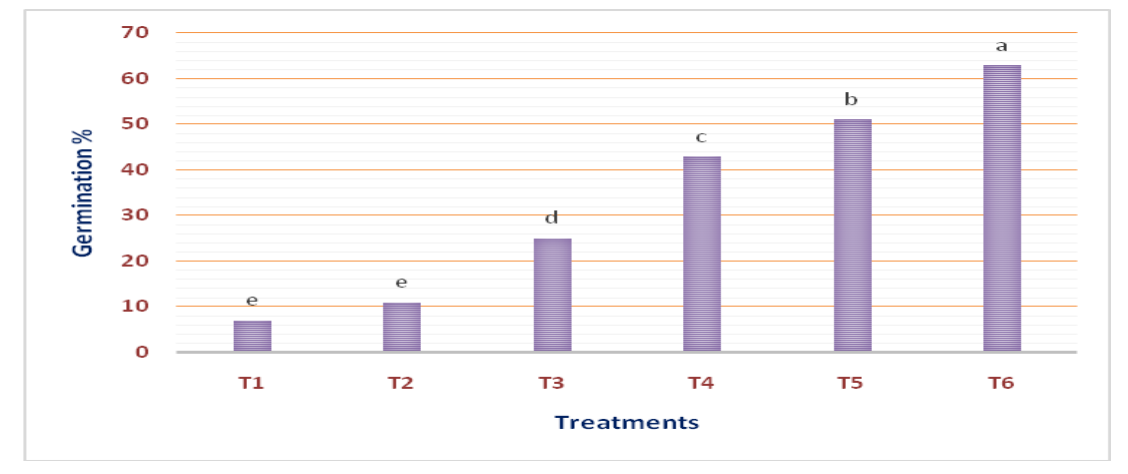

Fig.2 Effect of seeds treatment on DGS \& COV of Chloris barbata

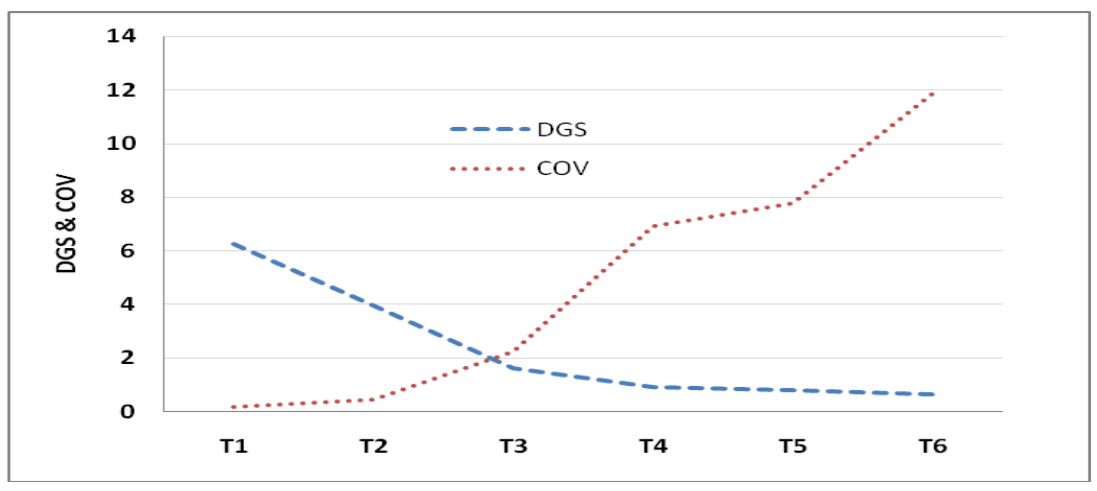

\section{Mean daily germination}

The mean daily germination of $C$. barbata was lower (0.18) in the control and it was on par with the soaking of seeds in water for 6 hrs (0.28). When seeds soaked for $12 \mathrm{hrs}$ in water $\left(\mathrm{T}_{3}\right)$ and treated with the $2 \% \mathrm{KNO}_{3}$ solution recorded significantly higher mean germination. Increasing in germination percentage and speed of germination due to the positive response of $C$. barbata seeds also significantly reflect on the mean daily germination.

\section{Daily germination speed (DGS)}

The higher daily germination speed (6.25) of $C$. barbata is recorded in the control treatment $\left(\mathrm{T}_{1}\right)$ and significantly low value of DGS is recorded in the treatment in which, 
seeds of $C$. barbata is treated in $2 \% \mathrm{KNO}_{3}$ solution with 12 hrs soaking $\left(\mathrm{T}_{6}\right)(0.64)$. Results shows that DGS decreased as treatments favours germination capacity of the seeds and its accordance with the findings of Reshma and Basavaraj (2019) reported DGS increased as water imbibition and germination capacity of the seeds declined with increasing salt concentration (Fig. 2).

\section{Coefficient of velocity of germination (CVG)}

Seeds treated in $2 \% \mathrm{KNO}_{3}$ solution with 12 hrs soaking $\left(\mathrm{T}_{6}\right)$ recorded significantly higher coefficient of velocity of germination (11.88) and lower coefficient of velocity of germination were resulted in the non-treated seed (control) (0.16). Busso et al., (2005) stated the coefficient of velocity of germination get increased when more number of seeds germinate in the lesser time and the value get decreased when less number of seeds took more days to germinate.

\section{Time to 50 percent germination}

Days to $50 \%$ germination is significantly influenced by the seeds treatments. Seeds treated in $2 \% \mathrm{KNO}_{3}$ solution with $12 \mathrm{hrs}$ soaking $\left(\mathrm{T}_{6}\right)$ shows significantly lesser number of day for $50 \%$ germination when compared to seeds treated with $\mathrm{KNO}_{3}$ without soaking. When soaking time decreases the $\mathrm{T}_{50}$ tends to increase. When compare the treatments without $\mathrm{KNO}_{3}$ higher day for $50 \%$ germination recorded in higher time of soaking. Soaking the seeds in water for 12 hours without $\mathrm{KNO}_{3}$ recorded a higher germination percentage when compared to $\mathrm{T}_{1} \& \mathrm{~T}_{2}$, so it took longer days to germinate. It is in accordance with the findings of Farooq et al., (2007) who reported that all the seed primed treatments reduced the time to $50 \%$ emergence compared with control.

\section{Peak value and Germination value}

The peak value and germination value was observed maximum in seedstreated in $2 \%$ $\mathrm{KNO}_{3}$ solution with 12 hrs soaking (1.75 and $2.77)$ and minimum in control $(0.23$ and 0.44).It might be due to the soaking duration, the value varied as the soaking time increases the peak value and germination value increased in the respective treatment (Cazabator, 1962).

\section{References}

Alboresi, A., C.Gestin, M. T. Leydecker, Bedu, C. Meyer, and H. N. Truong. 2005. Nitrate, a signal relieving seed dormancy in Arabidopsis. Plant, cell \&environment., 28(4): 500-512.

Basra, S.M.A., M. Farooq and R. Tabassum. 2005. Physiological and biochemical aspects of seed vigor enhancement treatments in fine rice (Oryza sativa L.). Seed Sci. Technol,. 33:623-628.

Busso, A.C., M. Mazzola and B.L. Perryman. 2005. Seed germination and viability of Wyoming Sagebrush in Northern Nevada. INCI., 30: 631-637.

Czabator, F. J. 1962. Germination value: An index combining speed and completeness of pine seed germination. Forest Science.,8:386-396. doi:10.1093/forestscience/8.4.386.

Danneberger, T.K., M.B. McDonald, C.A. Geron and P. Kumari. 1992. Rate of germination and seedling growth of perennial ryegrass seed following osmoconditioning. HortScience.,27:2830.

Farajollahi, A.,B. Gholinejad and H. JoneidiJafari. 2014. Effects of Different Treatments on Seed Germination Improvement of Calotropispersica. Advances in Agriculture., 1-5. 10.1155/2014/245686.

Farooq, M., S. M. A. Basra, M. Khalid, R. 
Tabassum and T. Mehmood. 2006. Nutrient homeostasis, reserves metabolism and seedling vigor as affected by seed priming in coarse rice. Can. J. Bot., 84: 1196-1202.

Jones, K and D. Sanders.1987. The influence of soaking pepper seed in water or potassium salt solutions on germination at three temperatures. Journal of Seed Technology., 11: 97-102.

Kant, S., S. S. Pahuja, and R. K. Pannu. 2006. Effect of seed priming on growth and phenology of wheat under late-sown conditions. Trop. Sci., 44: 9-15.

Kaur, S., A. K. Gupta and N. Kaur. 2005. Seed priming increases crop yield possibly by modulating enzymes of sucrose metabolism in chickpea. $J$. Agron. Crop Sci., 191: 81-87.

Kikuchi, K., M. Koizumi, N. Ishida and H. Kano, 2006. Water uptake by dry beans observed by micro-magnetic resonance imaging.Ann. Bot., 98: 545-553.

Lara, T. S., J. M. S. Lira A.C. Rodrigues, M.Rakocevi, and A. A. Alvarenga. 2014. Potassium nitrate priming affects the activity of nitrate reductase and antioxidant enzymes in tomato germination. Journal of Agricultural Science., 6(2): 72.

Maguire, J.D. 1962. Speed of germination-aid in selection and evaluation for seedling emergence and vigor. Crop Sci., 1962, 2: 176-177.

Orchard, T. 1977.Estimating the parameters of plant seedling emergence.Seed Science and Technology., 5: 61-69.

Patil, R. B. and B. A. Kore. 2019. Seed germination response of an invasive weed Alternantheraficoidea to temperature and salinity stress. Indian Journal of Weed Science., 51(4), 398401.

Roberts, E.1981.The interaction of environmental factors controlling loss of dormancy in seeds.Annals of Applied Biology., 98: 552-555.

Shim, S. I., J. C. Moon, C. S.Jang, P.Raymer, \& W. Kim. 2008. Effect of potassium nitrate priming on seed germination of seashore paspalum. HortScience., 43(7): 2259-2262.

Vyas, S. J. and J. Joshi. 2013. Salt-hormone interactions in seed germination of Chloris barbata Sw.International journal of research in Botany.,3(4): 5357

Zavariyan, A. M., M. Y. Rad and M.Asghari. 2015. Effect of seed priming by potassium nitrate on germination and biochemical indices in Silybummarianum L. under salinity stress. International Journal of Life Sciences., 9(1): 23-29.

\section{How to cite this article:}

Narmadha, R., T. Selvakumar, S. Srinivasan and Chinnamuthu, C. R. 2020. Enhancing Germination Capacity of Chloris barbata under In-vitro Conditions. Int.J.Curr.Microbiol.App.Sci. 9(11): 2738-2744. doi: https://doi.org/10.20546/ijcmas.2020.911.332 